\title{
The Teacher Role Guiding Students Entering Higher Education
}

\author{
Kusmiarso' $^{1}$, Suryadi², Siti Zulaikha3 \\ DOI: 10.35445/alishlah.v13i2. 804
}

Article Info

Keywords:

Higher Education; Guiding Program;

Teacher Role

Kata kunci:

Pendidikan Tinggi;

Program Bimbingan;

Peran Guru

\section{Abstract}

The uptake of students in state universities is the responsibility of teachers and schools in guiding them. Therefore, the purpose of the study was to find information related to teacher guidance for students to enter college. The research approach is qualitative through a survey. Data were collected through interviews, documents, and questionnaires. The data analysis process includes data collection, data reduction, data display and conclusion. The results showed that the data on student absorption in higher education during the last two years had increased. It provides an overview of the leading role of teachers in guiding students to enter college. From the questionnaire data, it can be seen that the data results support the increase in the number of students entering higher education. The results of this study can also be used as a reference for schools in developing guidance programs for students entering college.

\begin{abstract}
Abstrak
Keterserapan siswa di perguruan tinggi negeri menjadi tanggung jawab guru dan sekolah dalam membimbing mereka. Oleh karena itu, tujuan penelitian adalah untuk menemukan informasi terkait bimbingan guru kepada siswa untuk masuk perguruan tinggi. Pendekatan penelitian adalah kualitatif melalui survey. Data dikumpulkan melalui wawancara, dokumen, dan kuesioner. Proses analisis data meliputi pengumpulan data, reduksi data, penyajian data dan penarikan kesimpulan. Hasil penelitian menunjukkan data keterserapan siswa di perguruan tinggi selama 2 tahun terakhir mengalami peningkatan. Hal tersebut memberikan gambaran peran guru yang maksimal dalam membimbing siswa untuk masuk perguruan tinggi. Dari data kuesioner terlihat hasil data yang mendukung peningkatan jumlah keterserapan siswa masuk perguruan tinggi. Hasil penelitian ini juga dapat digunakan sebagai referensi bagi sekolah dalam mengembangkan program bimbingan siswa masuk perguruan tinggi.
\end{abstract}

\footnotetext{
${ }^{1}$ Universitas Negeri Jakarta, Indonesia

Email: arsodear@gmail.com

${ }^{2}$ Universitas Negeri Jakarta, Indonesia

Email: arsodear@gmail.com

3 Universitas Negeri Jakarta, Indonesia

Email: arsodear@gmail.com
} 


\section{INTRODUCTION}

The community has a high level of awareness of the need for higher education. At present, parents have a great desire for their children to continue their college education, which has led to increasingly fierce competition among students. Students must also try harder to follow various selection paths so that they can enter state universities. Some of the admission processes for state universities are the selection of report cards invitations (School and Student Database), the national selection to enter State Universities, to joint selection to enter State Universities. In this case, students must be able to understand the national or centralized selection process and the collective selection process depicted by decentralization (Hafalir et al., 2018). Therefore, schools have a huge responsibility and role in increasing students' absorption to enter higher education. The process of admitting students to higher education requires a quality that can meet the standards of the intended higher education institution (Lancaster et al., 2020). Thus, students must have prepared themselves with information related to the entry requirements for state universities to meet the qualifications set by the campus (Cahyono et al., 2019).

Universities in developing countries often face the double burden of increasing demand for higher education and a reduced share of the government's education budget. The cost-effective delivery of university education requires proper program design and admissions policies that do not compromise academic standards (Handa \& Gordon, 1999). In contrast to the country of Sri Lanka, the public university system in Sri Lanka is characterized by free tuition, central administration and affirmative action policies based on geographic areas aimed at reducing inequality in access to higher education (de Silva et al., 2021). It means that every country has an education system for the admission of new students to college. The goals can characterize it. China has recommended a new strategy for reforming the admissions process to create equity for all access to university (Jia \& Ericson, 2017).

In this case, Indonesia has a new student admission system at universities that have been adapted to the needs of each region through the principle of justice for all Indonesian citizens, as well as the same thing for everyone to get the same education. However, the selection process for entering public universities poses many challenges for schools in preparing quality students to meet university standards. Schools always make various efforts so that students get good test results and enter prestigious state universities in Indonesia because they can affect the school's image in society. Taiwan has tried to shift the pedagogy aimed at academic tests to be more holistic by including service-learning as a form of a sequence of student admissions in secondary schools (Liu, 2015).

However, the selection process for new student admissions at State Universities faces various problems, namely the disappointment of graduates who do not pass the selection by blaming schools or teachers associated with low levels of accreditation and school competence. With the absorption of quality graduates in State Universities, the good name and quality of schools are good in the general public's eyes. This perception occurs in all areas. The success of the school will be seen from the graduates who can enter State Universities. In addition, the determination of the quota for the distribution of entry points for State Universities that the government has set is also a consideration for schools in guiding students so that they can pass to enter higher education.

The absorption of students into State Universities cannot be separated from the role of teachers who have educated, guided, and motivated students to become the best graduates in schools to be accepted into State Universities. In addition, the guidance and counselling teachers also have a significant influence on the provision of services to foster interest in continuing their studies to college (Nisa, 2018). The role of the teacher is in line with the discipline and rules that apply in the school so that high school graduate students can pass the selection to enter State Universities. Schools must also build a culture and organizational structure that is in line with new adaptive ways of working and collaborating (Kunnari \& Ilomäki, 2016). To create it, teachers and students must have a two-way contribution that builds student readiness capabilities (Kearney \& Garfield, 2019). It means that the academic level, qualifications or school environment are required to meet each 
other's needs (Pradja, 2018). Thus, the teacher's knowledge and ability to teach enthusiastically, motivate students, involve families, respect differences and manage the classroom effectively is significant and impacts graduates (Dozza \& Cavrini, 2012).

In this case, the readiness of students to enter higher education depends on the role of the teacher during teaching and learning activities. Their professionalism is required to be able to give influence and hope to the community (Prenger et al., 2017). Therefore, this research was conducted on the grounds of the urgency of understanding all parties regarding the teacher's role in creating the success of students entering state universities. Whereas if, it is understood holistically that the success of students entering state universities does not depend on the teacher alone, this is a shared responsibility between teachers, parents, principals, and students. This means that the cooperation of all parties influences the quality of graduates.

However, this research focuses on teachers' role in preparing and guiding students to enter state universities. In this case, the perception of the teacher's role is taken from the perspective of students as the main subject for admission to state universities. In this study, the presentation that wants to be explored is related to the context of students' needs to be able to enter state universities. The readiness needed by students is by the standards and rules that apply in the admission of new students at the university.

Thus, the purpose of this study was to gain students' perspectives on the need for readiness to enter state universities. So, the research results can be used by schools as one of the evaluation materials in designing enrichment programs or guidance for students to enter state universities. In addition, this research is also expected to be useful for schools as a model for school management development on planning school quality improvement programs.

\section{METHODS}

This study used a qualitative approach using a survey. It explored the descriptive data in narration to describe the phenomenon or the fact in the field (Moleong, 2019). Descriptive research used a qualitative approach because the data collected in the field is data in words or behaviour, natural sentences and pictures, humans as instruments (Creswell \& Creswell, 2018). So, this research explains the students' perspective on the role of a teacher in guiding students to enter state university.

The participant in this study was students from the twelfth grade. They are 70 students $(\mathrm{M}=$ 38 and $\mathrm{F}=32$ ) in the 2019-2020 Academic Year. The data collected used a survey model, which used a questionnaire developed by the researcher. The questionnaire items have five items: totally disagree, disagree, neutral, agree, and totally agree. Besides, the data was collected too using interviews and documentation. The data analysis process includes data collection, data reduction, data display and conclusion (Miles \& Huberma, 1992). The process of data collection was from questionnaires and interviews. The questionnaire and interview are given to the students. Data reduction is made by categorizing the interview data relevant to the questionnaire distribution data. After that, the data presented using percentages in graph and taking conclusion to know the main finding of data.

\section{FINDINGS AND DISCUSSION}

The results of data analysis of interviews with students show that high school students have a high interest in continuing their education in college. However, the number of quotas that universities have set is not proportional to the number of registered students.

Table 1. Quota of State Universities based on entry routes for 2016-2020

\begin{tabular}{lccccc}
\hline \multicolumn{1}{c}{ Types of Selection } & 2016 & 2017 & 2018 & 2019 & 2020 \\
\hline National Selection to Enter State Universities & $40 \%$ & $30 \%$ & $30 \%$ & $20 \%$ & $20 \%$ \\
Joint Selection to Enter State Universities. & $30 \%$ & $30 \%$ & $30 \%$ & $40 \%$ & $40 \%$ \\
Independent Path Selection & $30 \%$ & $30 \%$ & $30 \%$ & $30 \%$ & $30 \%$ \\
\hline
\end{tabular}

Source: Ministry of Research and Technology of Higher Education, 2020 
Table 1. shows that the admission path for state universities from 2016 to 2020 has undergone changes, especially in the National Selection to Enter State Universities and Joint Selection to Enter State Universities. Meanwhile, the quota for the Independent selection is fixed every year, because the Independent selection is returned to every State University related to the examination procedures to accommodate students graduating from High School or Vocational High School to continue their education to a higher level. There is a higher percentage of the selection path for entering State Universities with those who carry out independent joint examinations of State Universities. It means that students who graduate from High School or Vocational High School have a variety of choices of State Universities and more diverse majors than taking the exam with the Independent Selection of State Universities. It can be seen from the number of registrants who tried to take the entrance exam to State Universities with the National Selection to Enter State Universities and Joint Selection to Enter State Universities from 2016 to 2020, as follows;

Table 2. Number of Registrants through the National Selection of State Universities

\begin{tabular}{lccccc}
\hline & $\mathbf{2 0 1 6}$ & 2017 & 2018 & 2019 & 2020 \\
\hline Registrants & $\mathbf{6 4 5 . 2 0 2}$ & 517.166 & 586.155 & 478.608 & 489.601 \\
Amount received & $\mathbf{1 1 5 . 1 7 8}$ & 101.906 & 110.946 & 92.331 & 96.496 \\
Percentage Received & $\mathbf{1 7 , 8 5 \%}$ & $19,70 \%$ & $18,93 \%$ & $19,29 \%$ & $19,71 \%$ \\
\hline \multicolumn{4}{l}{ Source: Ministry of Research and Technology of Higher Education, 2020 }
\end{tabular}

Table 3. Number of Registrants through the Joint Selection of State Universities

\begin{tabular}{lccccc}
\hline & 2016 & 2017 & 2018 & 2019 & 2020 \\
\hline Registrants & 721.326 & 797.738 & 860.001 & 714.652 & 702.420 \\
Amount received & 126.804 & 148.066 & 165.831 & 168.742 & 167.653 \\
Percentage Received & $17,5 \%$ & $14,36 \%$ & $19,28 \%$ & $23,61 \%$ & $23,87 \%$ \\
\hline \multicolumn{2}{l}{ Source: Ministry of Research and Technology of Higher Education, 2020 }
\end{tabular}

Based on the data in Tables 2 and 3, the number of applicants to continue higher education has increased. However, in the last two years, there has been a decline in applicants through the selection of the Number of Registrants through the Joint Selection. However, if we look at the results of the examinees accepted by State Universities, there has been a significant increase. The increase in the number of applicants entering State Universities has become so large as the competence of teachers and the quality of schools in each region has increased. This causes the competitiveness of high school graduates to increase in a certain period. From these data, it is known that the role of teachers in guiding students to enter State Universities is huge. This can also be seen in the following graph from the results of distributing questionnaires about the teacher's role to students in guiding them.;

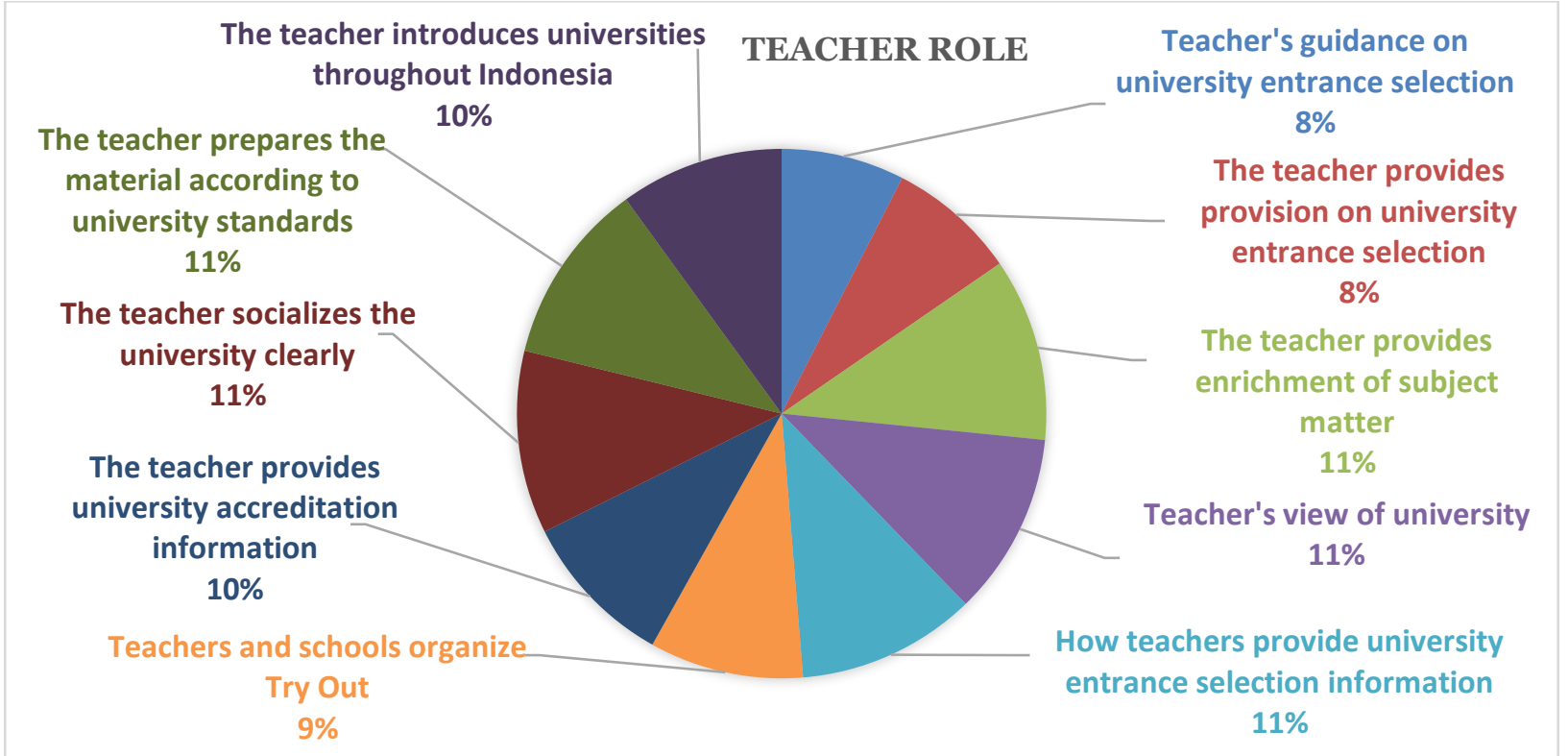

Graph 1. The Teacher Role in Guiding Students to Enter University 
The results of data analysis on the first question related to teacher guidance regarding university entrance selection were $64 \%$ from interviews with students that they still feel lacking in the university entrance selection process. This is because the teacher gives direction to only a few state universities. The teacher provides provisions regarding the selection of university entrance by $67 \%$. It means that teachers have made great efforts in equipping students with the university entrance selection process. This is still in line with question number 1 related to teacher guidance. The percentage results are still in the 60-70 range. The guidance and provisions provided have not fully met the students' needs for information related to the university entrance selection process. Therefore, teachers can direct students to provide information about studying at the university (van Rooij \& Jansen, 2018).

However, schools make enrichment programs for students as a form of enriching knowledge. This is the basic form of effort to prepare students for the selection test for entering state universities. The debriefing activity is given to students at the end of the ninth-grade semester. This, of course aims to be an essential part as the beginning of preparing for the transition period of student life from high school to college (McPhail, 2015). Thus, the academic performance of students in high school can be at a level above average. The material enrichment program is expected to increase students' low academic expectations (Bryce et al., 2021)

Teachers also always try to give their views about the university they want to go to. It is done in line with material enrichment activities in class. Various methods used by teachers have had a positive impact on students' needs. The school also continues to work closely with outside parties such as tutoring institutions to conduct test questions for students and try out selection tests for college entrance. Various school efforts and teacher guidance for students are aimed not to fail the college entrance test (Mittendorff et al., 2017). The existence of competition and high demands on the quality of higher education in this era of globalization encourage each university to improve the quality standards of its implementation to contribute to the nation's competitiveness. The role of the teacher is one of the essential factors to educate the nation's children. For this reason, teachers must work professionally according to teacher competency standards in Indonesia. As a critical factor in education, teachers must be ready and able to follow the development of science and technology, especially those related to education.

Thus, teachers significantly influence students' interest and motivation to continue their studies at public or private universities. Several points related to the findings of the teacher's role in supporting students to enter higher education are:

1. The teacher provides a study guide for the college entrance selection test. The school provides tutoring programs in preparation for university entrance tests.

2. Teachers also often explain the university entrance selection process according to the latest regulations.

3. Material enrichment is provided by the teacher according to the needs of students and the development of the college entrance selection system

4. Teachers also often provide information related to the learning system at universities and life in college

5. The teacher has tried to provide material and information by university standards

6. The teacher provides the latest information regarding public and private universities throughout Indonesia

\section{CONCLUSION}

The results of data analysis concluded that teachers at schools had guided students very well, starting from material enrichment, test trials, information about state universities, and the selection process for entering state universities. This study found an understanding that the influence of teacher discipline guides students on student achievement. Teachers must work professionally according to teacher competency standards in Indonesia. As a key factor in the world of education, 
teachers must, of course, be ready and able to follow the development of science and technology and the development of various regulations that have been issued by the government related to university admission policies.

This research is still limited to the role of teachers in guiding students to enter state universities. The process of entering private universities has not been described nor the role of school management in managing programs to increase the number of students entering public universities. Therefore, this research can be developed again in the realm of school management in improving student achievement and the number of students entering state universities. In addition, this study also recommends that schools make teacher competency development programs to improve their professionalism or as a basis and reference for further research related to school discipline, the role of teachers, and student absorption in State Universities.

\section{REFERENCES}

Bryce, C. I., Fraser, A. M. J., Fabes, R. A., \& Alexander, B. L. (2021). The role of hope in college retention. Learning and Individual Differences, 89, 102033. https://doi.org/10.1016/J.LINDIF.2021.102033

Cahyono, A., Pramono, B., \& Oganda, F. P. (2019). Design of Information System in Admission of New Students Based on Web in SMK Al Amanah. Aptisi Transactions on Management (ATM), 3(2), 159-167. https://doi.org/10.33050/atm.v3i2.1034

Creswell, J. W., \& Creswell, J. D. (2018). Research Design: Qualitative, Quantitative, and Mixed Methods Approaches Fifth Edition. SAGE Publications Inc.

de Silva, T., Gothama, S., \& Premakumara, P. (2021). Admissions quotas in university education: Targeting and mismatch under Sri Lanka's affirmative action policy. International Journal of Educational Development, 84, 102440. https://doi.org/10.1016/j.ijedudev.2021.102440

Dozza, L., \& Cavrini, G. (2012). Perceptions of Competence: How Parents View Teachers. Procedia Social and Behavioral Sciences, 46, 4050-4055. https://doi.org/10.1016/J.SBSPRO.2012.06.195

Hafalir, I. E., Hakimov, R., Kübler, D., \& Kurino, M. (2018). College admissions with entrance exams: Centralized versus decentralized. Journal of Economic Theory, 176, 886-934. https://doi.org/10.1016/j.jet.2018.05.009

Handa, S., \& Gordon, P. J. (1999). University admissions policy in a developing country: Evidence from the University of the West Indies. Economics of Education Review, 18(2), 279-289. https://doi.org/10.1016/So272-7757(98)oo039-9

Jia, Q., \& Ericson, D. P. (2017). Equity and access to higher education in China: Lessons from hunan province for university admissions policy. International Journal of Educational Development, 52, 97-110. https://doi.org/10.1016/j.ijedudev.2016.10.011

Kearney, W. S., \& Garfield, T. (2019). Student Readiness to Learn and Teacher Effectiveness: Two Key Factors in Middle Grades Mathematics Achievement. Https://Doi.Org/10.1080/19404476.2019.1607138, $\quad$ 42(5), 1-12. https://doi.org/10.1080/19404476.2019.1607138

Kunnari, I., \& Ilomäki, L. (2016). Reframing teachers' work for educational innovation. Innovations in Education and Teaching International, 53(2), 167-178. https://doi.org/10.1080/14703297.2014.978351

Lancaster, R. J., Baseman, E., \& Smolinski, L. (2020). A quality improvement project: Defining and operationalizing a holistic admission selection policy. Journal of Professional Nursing, 36(4), 259-263. https://doi.org/10.1016/j.profnurs.2020.01.003

Liu, T.-M. (2015). Junior High School Students' Perceptions of Service Learning for Admission to High School. Procedia - Social and Behavioral Sciences, 197, 75-82. https://doi.org/10.1016/j.sbspro.2015.07.055

McPhail, R. (2015). Pre-university prepared students: a programme for facilitating the transition from secondary to tertiary education. Teaching in Higher Education, 20(6), 652-665. https://doi.org/10.1080/13562517.2015.1062360

Miles, \& Huberma. (1992). Analisis Data Kualitatif. Universitas Indonesia Press.

Mittendorff, K., Faber, M., \& Staman, L. (2017). A matching activity when entering higher education: ongoing guidance for the students or efficiency instrument for the school? Http://Dx.Doi.Org/10.1080/o3069885.2017.1285392, 45(4), 376-390. 
https://doi.org/10.1080/03069885.2017.1285392

Moleong, L. J. (2019). Metodologi Penelitian Kualitatif(Edisi Revisi). Rosdakarya.

Nisa, A. (2018). Peran Guru Bimbingan dan Konseling Dalam Meningkatkan Minat Melanjutkan Studi ke Perguruan Tingg. KONSELI: Jurnal Bimbingan Dan Konseling (E-Journal), 5(1), 01o8. https://doi.org/DOI: http://dx.doi.org/10.24042/kons.v5i1.2508

Pradja, N. S. (2018). Analysis of Teacher Competence Social Studies (The Influences of Academic Qualification, Education and Training, and Principal Leadership on Work Motivation and Their Implications on Teacher Competency in State Junior High Schools in Kuningan Regency). Equilibrium: Jurnal Penelitian Pendidikan dan Ekonomi. Equilibrium: Jurnal Penelitian Pendidikan Dan Ekonomi, 15(2), 34-43. https://doi.org/10.25134/equi.v15io2

Prenger, R., Poortman, C. L., \& Handelzalts, A. (2017). Factors influencing teachers' professional development in networked professional learning communities. Teaching and Teacher Education, 68, 77-90. https://doi.org/10.1016/J.TATE.2017.08.014

van Rooij, E. C. M., \& Jansen, E. P. W. A. (2018). "Our job is to deliver a good secondary school student, not a good university student." Secondary school teachers' beliefs and practices regarding university preparation. International Journal of Educational Research, 88, 9-19. https://doi.org/10.1016/J.IJER.2018.01.005 